Article

\title{
Vaccine Assemblages on Three HPV Vaccine-Critical Facebook Pages in Denmark from 2012 to 2019
}

\author{
Torben E. Agergaard *, Màiri E. Smith and Kristian H. Nielsen \\ Centre for Science Studies, Aarhus University, 8000 Aarhus C, Denmark; E-Mails: ta@css.au.dk (T.E.A.), \\ mairi.e.smith@gmail.com (M.E.S.), khn@css.au.dk (K.H.N.) \\ * Corresponding author
}

Submitted: 31 January 2020 | Accepted: 6 April 2020 | Published: 26 June 2020

\begin{abstract}
Misinformation about vaccines on social media is a growing concern among healthcare professionals, medical experts, and researchers. Although such concerns often relate to the total sum of information flows generated online by many groups of stakeholders, vaccination controversies tend to vary across time, place, and the vaccine at issue. We studied content generated by administrators on three Facebook pages in Denmark established to promote critical debate about Human Papillomavirus (HPV) vaccination. We developed a qualitative coding frame allowing us to analyze administrators' posts in terms of prevalent topics and intertextual material incorporated by linking and sharing. We coded more than a third of the posts ( $n=699$ ) occurring in the period from November 2012, when the first page was founded, to May 2019. We found that the pages mainly addressed the reports of adverse events following HPV vaccination and the (perceived) inadequate response of healthcare systems. To construct their central message, the pages assembled different sources, mostly reporting from Danish news media, but also personal narratives, scientific information, political assertions, and more. We conclude that HPV vaccination assemblages such as these pages are heterogeneous and contextual. They are not uniform sites of vaccine criticism, but rather seem to respond to and exchange information and misinformation within the communication environment in which they are embedded.
\end{abstract}

\section{Keywords}

controversy; Denmark; Facebook; Human Papillomavirus; misinformation; qualitative content analysis; social media; vaccination

Issue

This article is part of the issue "Health and Science Controversies in the Digital World: News, Mis/Disinformation and Public Engagement" edited by An Nguyen (Bournemouth University, UK) and Daniel Catalan (University Carlos III of Madrid, Spain).

(C) 2020 by the authors; licensee Cogitatio (Lisbon, Portugal). This article is licensed under a Creative Commons Attribution 4.0 International License (CC BY).

\section{Introduction}

Misinformation about vaccines is a widespread concern among researchers and healthcare professionals. The term misinformation usually means wrong or faulty information, and often the point of reference is scientific information. Medical authorities, expert groups, and individual researchers worry that vaccine misinformation flourishing in media environments may lead to vaccine hesitancy and ill-informed political or juridical decisions (e.g., Burki, 2019; Ghebreyesus, 2019; Larson, 2018). The affordances of the internet and social media enable users to contribute to the global flow of vaccine information in unprecedented ways, while building relations across geographical and institutional borders, forming shared narratives, and possibly affecting actions (Bucher \& Helmond, 2017). The sources of vaccine misinformation on the web range from small, but often well-organized interest groups, which deliberately spread false information about vaccines, to well-meaning individuals who take it upon themselves to act as "nonprofessional risk communicators" (Kahan, 2017). Medical authorities around the 
world are concerned about the total effects of such communicative efforts.

Partly in response to concerns over the intensification and diversification of vaccine information, scholars have advanced our understanding of online vaccine criticism. Some studies have focused on homepages and blogs (Bean, 2011; Kata, 2012; Moran, Lucas, Everhart, Morgan, \& Prickett, 2016; Okuhara, Ishikawa, Okada, Kato, \& Kiuchi, 2018; Ward, Peretti-Watel, Larson, Raude, \& Verger, 2015; Wolfe, Sharp, \& Lipsky, 2002). Others have analyzed vaccine-related content on popular social media platforms such as Twitter, Pinterest, YouTube, Instagram, and Facebook (see, for example, Basch \& MacLean, 2019; Guidry, Carlyle, Messner, \& Jin, 2015; Hoffman et al., 2019; Ma \& Stahl, 2017; Schmidt, Zollo, Scala, Betsch, \& Quattrociocchi, 2018; Smith \& Graham, 2017; Tomeny, Vargo, \& El-Toukhy, 2017; Yiannakoulias, Slavik, \& Chase, 2019). Though concepts such as the 'anti-vaccination movement' and 'anti-vaxxers' are often evoked in the public and in academic debate, studies tend to show that vaccine-critical groups and individuals are in fact heterogeneous, and that the discourses they employ vary from one context to another (see also Ortiz, Smith, \& Coyne-Beasley, 2019).

These findings underscore the importance of paying closer attention to the differentiated nature of vaccinecriticism and vaccine-critical information. In his study of the swine flu vaccine controversy in France, Ward (2016) concluded that a minority of critical groups and individuals mobilized against vaccination in general while most were only occasionally active and only critical of a given vaccine based on particular arguments. Ward's (2016) study shows that the prevalence of concerns, topics, and discourses often rely upon the contextual nature of the communication environment in which vaccine controversies take place and therefore vary across time, geographical settings, and the vaccine(s) at issue (see also Leach \& Fairhead, 2007). This means that cultural and political issues beyond vaccines themselves affect information and communication about vaccination (Kahan, 2017; Ward, Peretti-Watel, \& Verger, 2016).

Kahan (2017) coined the notion of the vaccine communication environment to designate the "sum total of practices and cues that orient individuals in relation to what is known by science." The vaccine communication environment is 'safe' as long as everyone communicating about vaccines recognizes what counts as best available scientific evidence about vaccine efficiency and safety. The environment becomes 'polluted' when information with no or little relevance to the scientific risk assessment is being introduced into the environment, thus making it more difficult for parents and others to discern what is known by science. In the US, the Human Papillomavirus (HPV) vaccine debate became polluted by terms such as the 'promiscuity vaccine' or the 'virgin vaccine,' which implied that the female-only vaccine would lead to increased and unprotected sex among vaccinated girls and young women. Kahan, Braman, Cohen, Gastil, and Slovic (2010) found that, as a result, cultural values affected people's processing of scientific information about the vaccine.

We follow Ward (2016) in addressing the contextual nature of vaccine criticism as well as Kahan (2017) in trying to probe the conflation of scientific and non-scientific information in the vaccine communication environment. Thus, we are not interested in sorting information from misinformation. Rather, our aim is to study what we, inspired by Latour's (2005) work on the assembling of the social, will refer to as 'vaccine assemblages.' In a multimodal communicative context such as social media, vaccine assemblages result from combining many pieces of information and different modes of communication about vaccination into a heterogeneous, shifting and contextual whole. Thus, vaccine assemblages relate to Leach and Fairhead's (2007) concept of vaccine anxiety, which implies that streams of content on social media platforms, much like mothers' talk about vaccination, assembles scientific information about vaccines, personal narratives related to vaccination, objective reporting, value assertions about healthcare, and much more. To study vaccine assemblages on Facebook, we identified three Facebook pages in Denmark established to facilitate and promote critical debate about the HPV vaccine. The content provided by pages such as these has been a particularly critical part of the Danish HPV vaccine communication environment, where scientific information provided by the health authorities met other types of information and other modes of communication from other sources.

\section{Background}

HPV is a group of common viruses, mainly transmitted through sexual contact. Some high-risk types, including HPV-16 and HPV-18, are known to cause cancers, such as cervical cancer. In 2007, a working group commissioned by The Danish Health Authority (Sundhedsstyrelsen) carried out a medical technology assessment. Based on available empirical evidence, they estimated that around $70 \%$ of all cervical cancer cases, accountable for approximately 175 deaths annually in Denmark, could be prevented by offering Danish girls the quadrivalent HPV vaccine Gardasil through the childhood immunization program (Sundhedsstyrelsen, 2007). The Danish parliament unanimously approved to introduce the vaccine by January 2009, targeting girls at the age of 12 years.

Within the first years after the introduction, the support for the HPV vaccination program in Denmark was relatively high compared to other developed countries (European Centre for Disease Prevention and Control, 2012). In 2013, however, the vaccine began to receive negative media coverage. First, a journalist on the broadsheet newspaper Politiken reported on possible conflicts of interest among some general practitioners who were receiving support from Sanofi Pasteur, the multinational pharmaceutical company involved in the manufacturing and promotion of Gardasil in Denmark. A few weeks later, 
the same journalist wrote about a named girl suffering from a serious illness after receiving the second dose of the HPV vaccine. The journalist used Facebook to search for other girls with suspected adverse events, and the request soon circulated on Danish social media and blogosphere. Similar stories appeared in national and local media with girls, their families, and a few health professionals as sources (Smith, 2018; Suppli et al., 2018).

On March 26, 2015, the national public-service broadcaster TV2 screened the documentary The Vaccinated Girls-Sick and Betrayed. The documentary and subsequent news items revolved around 47 Danish girls suffering from headaches, cramps, syncope, and extreme fatigue. Some of them had been diagnosed with Postural Orthostatic Tachycardia Syndrome (POTS) or Complex Regional Pain Syndrome (CRPS). They all reported that the symptoms first appeared or significantly worsened following HPV vaccination. About 500,000 (out of a total population of 5.7 million in 2015) persons viewed the documentary, and it was widely discussed in the news and on social media. Suppli et al. $(2018$, p. 2) note that the documentary accelerated the negative coverage of the HPV vaccine, which "was followed by a marked decline in HPV-vaccination and an increased rate of reported suspected adverse events."

Due to the increased amount of reporting on potential adverse events, the Danish Health Authority requested a review of HPV vaccines by the European Medicines Agency (EMA). In November 2015, EMA concluded that evidence did not support that HPV vaccines cause POTS or CRPS, and that reports about suspected adverse events after HPV vaccination were consistent with what would be expected in this demographic group (EMA, 2015). However, the EMA report did not bring the controversy to a close. The media continued to report cases of suspected adverse events, and the report became subject to debate about the evidential support of its claims. Around the same time as the publication of the EMA report, the free newspaper metroxpress initiated its critical HPV campaign that drew on information from groups supporting the afflicted girls and their families. The number of girls who received HPV-vaccination continued to decline.

In May 2017, the Danish Health Authority, in collaboration with the Danish Medical Association and the patient advocacy organization the Danish Cancer Society, launched the Stop HPV campaign. Consultant to the Society, Louise Hougaard Jakobsen, explained that "[much] of the debate about the HPV vaccine takes place on Facebook, and this is where many parents get their information" (as cited in World Health Organization, 2018). Jakobsen herself had conducted a survey in 2016 among 1,053 parents of girls aged $10-13$ years. It showed that more than $80 \%$ of the respondents who reported having actively sought information about the vaccine had used the internet as a source of information (Jakobsen, 2016).

The Stop HPV campaign generally received positive coverage. Most news media began cautioning against the decline in HPV vaccination uptake. Reporters, editors, and others blamed the 2015 TV2 documentary for excessive emotionalism and for failing to report the facts about HPV vaccination. Commentators from academia and the health authorities interpreted the whole HPV controversy in the light of fake news and the spread of misinformation on social media (Smith, 2018). In 2017 and 2018, HPV vaccination rates rose (Statens Serum Institut, 2019).

\section{Materials and Methods}

Facebook content seems to have played an important role in the HPV controversy in Denmark where the vaccine information environment became 'polluted' as news media and social media increasingly reported on adverse events following HPV vaccination that were not substantiated by scientific evidence. We were interested in studying content provided by vaccine-critical Facebook pages (henceforth pages). We, therefore, searched Facebook using search string such as 'hpv,' 'hpv vaccine,' and 'hpv vaccine bivirkning*' ('hpv vaccine adverse event*'). Based on the results, we identified the most popular HPV-critical pages in Denmark in terms of likes and followers. In the following sections, we present the three pages and our analytic approach.

\subsection{Three Vaccine-Critical Groups and Their Pages}

The three pages were established by the following social groups, which for the sake of brevity we will refer to as Group A, B, and C, and to their pages as Page A, $B$, and $C$ (see list below). We last accessed the three pages in the middle of December 2019, when they were all still active. Here, some 5,900 Facebook users liked Page A, while Page B and C had around 8,100 and 1,800 likes, respectively.

- Group A: HPV Vaccine Info-Fighting for Fair Information about The HPV Vaccine (HPV Vaccine Info-Til kamp for retfærdig oplysning om HPVvaccinen)

- Group B: HPV Update (HPV-update)

- Group C: The National Organization for Those Afflicted by HPV Adverse Events (Landsforeningen HPV-Bivirkningsramte)

Group A consists of an unknown number of "passionate writers," who created the page in November 2012 (HPV Vaccine Info, 2020). Groups B and C are both patient support groups, established to support patients suspecting their symptoms to be caused by HPV vaccination. Group B is a special group under The Danish Association of the Physically Disabled, which is an NGO aiming to ensure equal rights and accessibility for persons with physical disabilities. Group $C$ is an independent organization. Page B dates from November 2014, Page C from May 2015. Each of the three groups also hosted 
their own website, and two of them were moderately active on other social media platforms such as Twitter and YouTube. We found that the groups' Facebook pages were the most important channels for public outreach.

Group B considers themselves "neither for nor against the HPV vaccine" (HPV-update, 2017). The two others do not specify a particular attitude towards HPV vaccination. On their respective pages, the three groups provide information on critical issues related to HPV vaccination, and they are most often critical of the information provided by the health authorities and organizations in support of the vaccine.

\subsection{Sampling Strategy}

We accessed all posts on all three pages from November 2012 (when Page A was established) to May 2019 (when the activity level on Pages $A$ and $B$ had dropped to nearly zero). We collected information about the total number of monthly posts on all three pages and then decided to construct a sample corpus of about one-third of all posts. We wanted the number and distribution of posts in our sample corpus to be as representative of the full corpus of posts as possible. We also wanted to make sure that months with a low level of activity were represented in our sample corpus. So, we sampled for each month post number one, four, seven, etc. This resulted in a sample corpus consisting of 699 posts.

\subsection{Qualitative Content Analysis}

In order to collect systematic information about the content provided on the three pages, we chose to conduct a qualitative content analysis of all posts in our sample corpus. Following Schreier (2012), we constructed our coding frame around two main categories: topic and source. This frame nicely captured the two basic elements of posts, namely content authored by administrators (topic) and the optional linking to other sites on the internet or sharing of material from other sites (source). The full coding frame, including definitions and examples, is available by request from the authors.

We generated subcategories for the topic category in our coding frame through a data-driven, iterative process, relying on the interrelated strategies of summarization and subsumption (Schreier, 2012, p. 88). Reading the content of the posts, we first summarized the material by paraphrasing content in short sentences or keywords and then used the paraphrases to generate potential subcategory names. We subsumed different potential subcategories under one, if possible, to achieve the lowest number of operational subcategories that describe the material in fullest detail (see Table 1).

As regards to the source category, we employed a combined concept and data-driven strategy (Schreier, 2012, pp. 89-90). We relied on Fairclough's (2003, pp. 47-55) notion of intertextuality to alert us to additional meanings generated by the presence of links to external sources in posts. Based on the material available in our sample corpus, we then operationalized intertextuality in our coding scheme by expanding the source category to include three main categories: language, linked items (for example, videos, images, tweets, or other Facebook posts), and source of information (namely the actors, i.e., a person, group, or organization that has authored or published the external source). Each of these categories has a number of subcategories (see Table 1).

It should be noted that posts often incorporated sources from more than one external platform. For practical reasons, we coded only one source per post in the following way: If a link was highlighted in the header of the post, we coded the highlighted link. If no link was highlighted, we coded the first link in the post (from top to bottom). Even if a post has no links, the post still may incorporate external items in another way, for example by sharing images or Facebook content from other profiles or pages, or by copy-pasting full-length texts or elements of texts from external sources. If this was the case, we located the original item and coded it in accordance with our categories.

Table 1. Coding frame with categories and subcategories.

\begin{tabular}{ll}
\hline Categories & Example \\
\hline Topic & $\begin{array}{l}\text { Adverse events, effect of vaccine on cancer, healthcare system (local), } \\
\text { healthcare system (national), healthcare system (international), vaccines in general, } \\
\text { alternative healthcare, news media, political actors, no topic, no administrator content }\end{array}$ \\
Language & Danish, English, Norwegian or Swedish, other, unknown or N/A, no external element \\
Linked item & $\begin{array}{l}\text { Website article, Facebook content, other social media content, audio or video, blog post, } \\
\text { scientific publication, open letter or public statement (e.g., press release or reader's letter), } \\
\text { shared picture or meme, event, other, unknown, no external element }\end{array}$ \\
Source of information & $\begin{array}{l}\text { Group's own homepage, content provided by the two other groups in this study, } \\
\text { Danish news media, non-Danish news media, other vaccine group, patient group, } \\
\text { other organization or company, health authority or institution, journal, private person, other, } \\
\text { unknown, no external element }\end{array}$ \\
\hline
\end{tabular}




\subsection{Reliability}

For an initial assessment of the reliability of our topic category and the included subcategories, we compared it to categories found in previous studies of vaccine criticism online (Bean, 2011; Moran et al., 2016; Okuhara et al., 2018; Ward et al., 2015). We found what we think is a reasonable agreement between our subcategories and those employed in other studies.

We then constructed and assessed the reliability of our entire coding frame through an iterative process. Initially, all three authors discussed the coding frame and agreed on all subcategory names, definitions, and examples. Two authors then independently coded a random selection of around $10 \%$ of the 699 posts.

In order to validate our coding of the 'language' and the 'source of information' categories, where categories are disjoint, we used Cohen's $\kappa$ to measure inter-coder reliability (Cohen, 1960). For the 'linked item' category, where posts occasionally were coded in more than one of the subcategories, which makes the risk of agreement by chance very low, we checked for agreement between coder and co-coder on all co-coded posts and, as a measure of inter-coder reliability, we calculated the percentage of agreement. For the 'topic' category, where posts could fall into one or more sub-categories, we assessed the applicability and reproducibility of each of the sug- gested subcategories. We then compared coding results one by one via Cohen's $\kappa$.

We aimed for inter-coder reliability indices above 0.8 as this is often considered to be acceptable (Lombard, Snyder-Duch, \& Bracken, 2002). If we were unable to reach an acceptable agreement, we stabilized the coding frame by removing problematic subcategories or clarifying coding instructions. After the reliability of our categories and subcategories had been established, one author proceeded to code all remaining posts.

\section{Results}

\subsection{Coding Frame}

Our coding frame is, in principle, our first result (see Table 1). It defines what we believe are the most prevalent and thus most important categories and subcategories for analyzing content on the three pages.

\subsection{Post Frequency}

The frequency of posts per month is shown in Figure 1. The activity level differs greatly between pages and between months. Page A has 4.1 monthly posts on average, whereas the corresponding numbers for Page $B$ and $C$ are 10.0 and 21.1 , respectively. The maximum numbers of

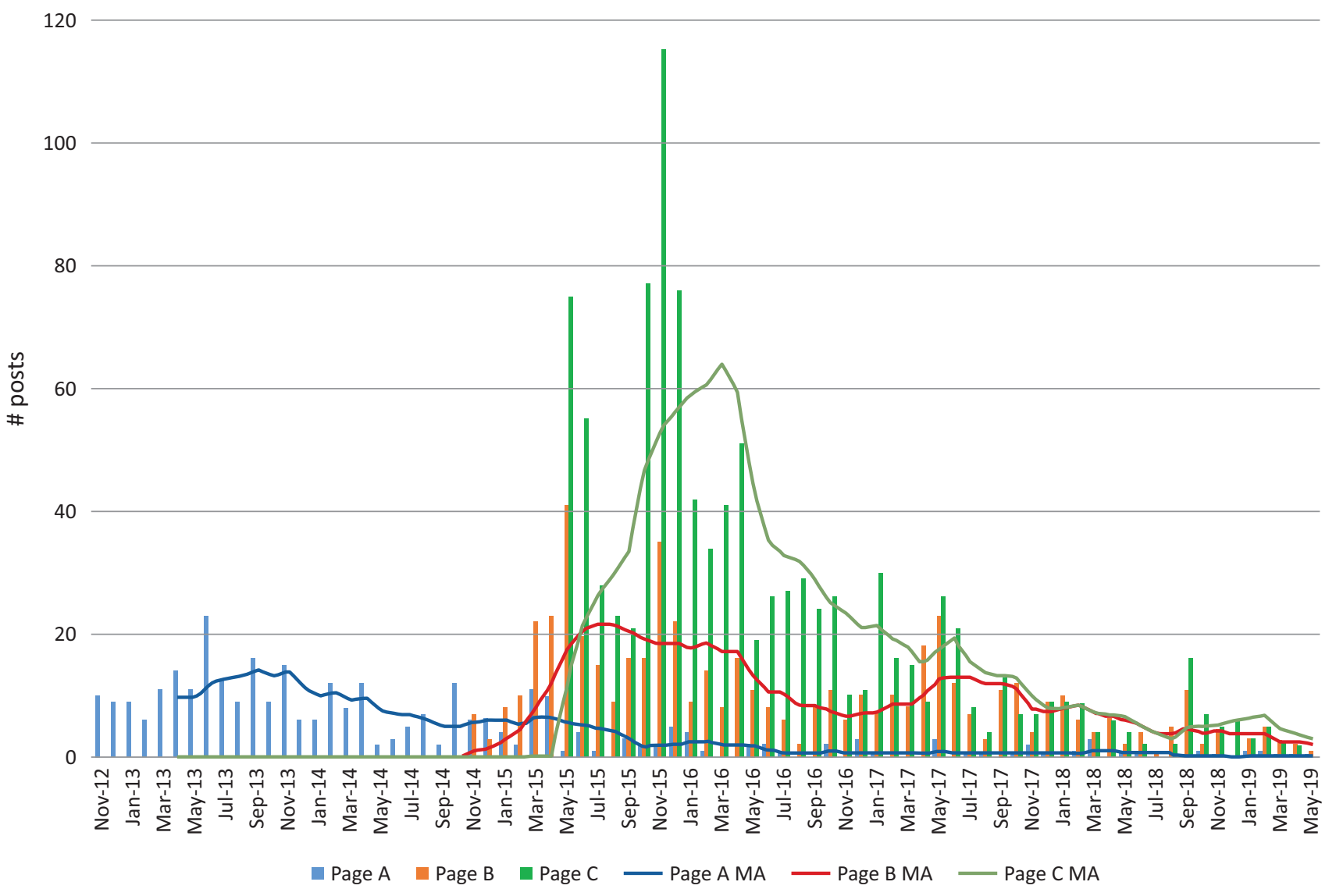

Figure 1. Frequency of posts from November 2012 to May 2019 with corresponding six month simple moving averages. Note: Our count was last updated on December 13, 2019. 
posts in a particular month are 23 posts for Page $A$ in June 2013, 41 posts for Page B in May 2015 and 115 posts for Page $C$ in November 2015. All three pages were most active in the first 1.5 years, and the activity level on all three pages reached a peak between six and eight months after their establishment. Moreover, local peaks in activity level on all pages often coincided with central events in the Danish HPV debate. Figure 1 has four peaks corresponding to important events in the Danish HPV controversy (cf. background above):

1. Summer of 2013 (Page A only): First media coverage of reported adverse events

2. April-May 2015: After the screening of "The Vaccinated Girls" on TV2

3. November 2015: Publication of the EMA report and critical HPV coverage in the free newspaper metroxpress

4. May 2017: Launch of Stop HPV campaign

\subsection{Topics}

Our coding of topics featured in the content provided by administrators appears in Figure 2. The two most promi- nent topics on all three pages were adverse events following HPV vaccination and healthcare systems, which were also the prominent topics in the general public debate as described earlier (Amdisen, Kristensen, Rytter, Mølbak, \& Valentiner-Branth, 2018; Suppli et al., 2018). Our results show that the three HPV vaccinecritical groups on their respective pages responded to the ongoing controversy by focusing on the safety of HPV vaccination (adverse events) and the actions of health authorities.

In Figure 2, the healthcare system subcategory subsumes the three levels of healthcare systems presented in Table 1. We can add that across all three pages the national healthcare system featured most frequently in the content provided by administrators. In particular, the three institutions that in 2017 were behind the Stop HPV campaign received most mentions, and, almost exclusively, administrators' posts were critical of the campaign.

Figure 2 also shows important differences between the three pages. Compared to Page A, Page B and C had a more narrow focus on potential adverse events. The administrators on Page A more frequently posted content relating to the effect of HPV vaccination on cancer,

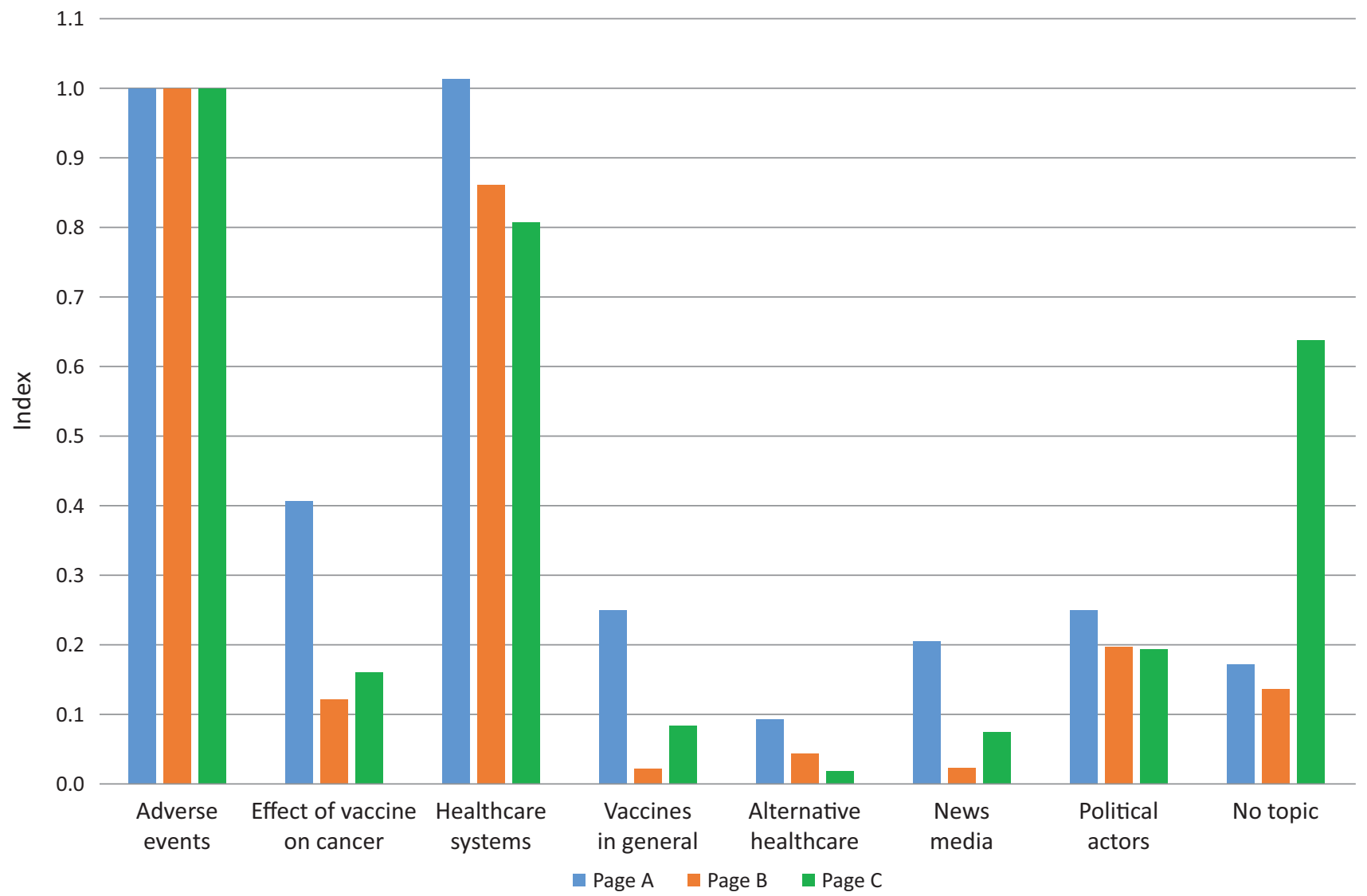

Figure 2. Relative frequencies of topics normalized by the frequency of 'adverse events' (1.0) for each page. Notes: The healthcare systems category in this figure subsumes the three levels in the healthcare system subcategory presented in Table 1 (local, national, and international). We explain the high rate of 'no topic' posts on Page $C$ by the fact that posts may refer to more than one topic, and lengthy posts therefore tend to produce more topics in the coding process compared to shorter ones. Page $C$ posts tended to be shorter compared to posts on Page $A$ and $B$, and shorter posts tended to be topicless. 
vaccines in general, alternative healthcare, and the news media. We would explain this observation by the fact that Page $A$ was administered by a group of writers more broadly interested in many topics relating to HPV vaccination, whereas Page $B$ and $C$ belonged to patient groups.

Relatively few posts pertained to vaccines in general or to alternative treatments. News media and political actors, i.e., institutions or individuals that have some measure of political power or authority when it comes to policymaking, also featured relatively infrequently in the content provided by administrators. So did the effect of HPV vaccines on cancers associated with HPV, most typically cervical cancer. The administrators of Page $A$, however, did cover this topic about $40 \%$ of the times they mentioned adverse events. All of their comments on the effects of HPV vaccines were skeptical about studies or comments indicating that HPV vaccination would tend to decrease the number of new cervical cancer cases.

\subsection{Intertextuality on Page A}

The administrators of Page $A$, in their posts from November 2012 to June 2013, most frequently provided links to international news media (see Figure 3). Some of these links referred to national news outlets such as CNN (primarily USA) or the Australian tabloid me- dia The Daily Telegraph. Others, more typically, shared material from media with a more limited circulation. For example, one post on Page A shared an article from Idaho Mountain Express, headlined "HPV vaccine is not the right solution," while other posts linked to American right-wing news outlets such as Alex Jones' Prison Planet and USA. RightWingAmerica, known to publish anti-vaccination material. In addition, media outlets advocating 'natural' alternatives to conventional healthcare such as the website Natural News recurred as a source of information on the page in its early stages.

However, the international element was not a stable feature of Page A's information stream. During 2013, links to Danish news media began to dominate. The linked news items included stories about individual concerns over the safety of the vaccine with headlines such as "Simone received the HPV vaccine: I feel pain every single day," and "Rebecca wanted to protect herself against cancer: Crippled by the vaccine." Yet, the administrators also found a reason to criticize media coverage. A post from late June 2013 contained a collage of media headlines, all of which referred to the HPV vaccine as a "cervical cancer vaccine" (HPV Vaccine Info, 2013a, authors' translation). The administrators supplied the collage with a red-letter stamp stating "it is not a vaccine against cancer" (HPV Vaccine Info, 2013a, authors' trans-

30

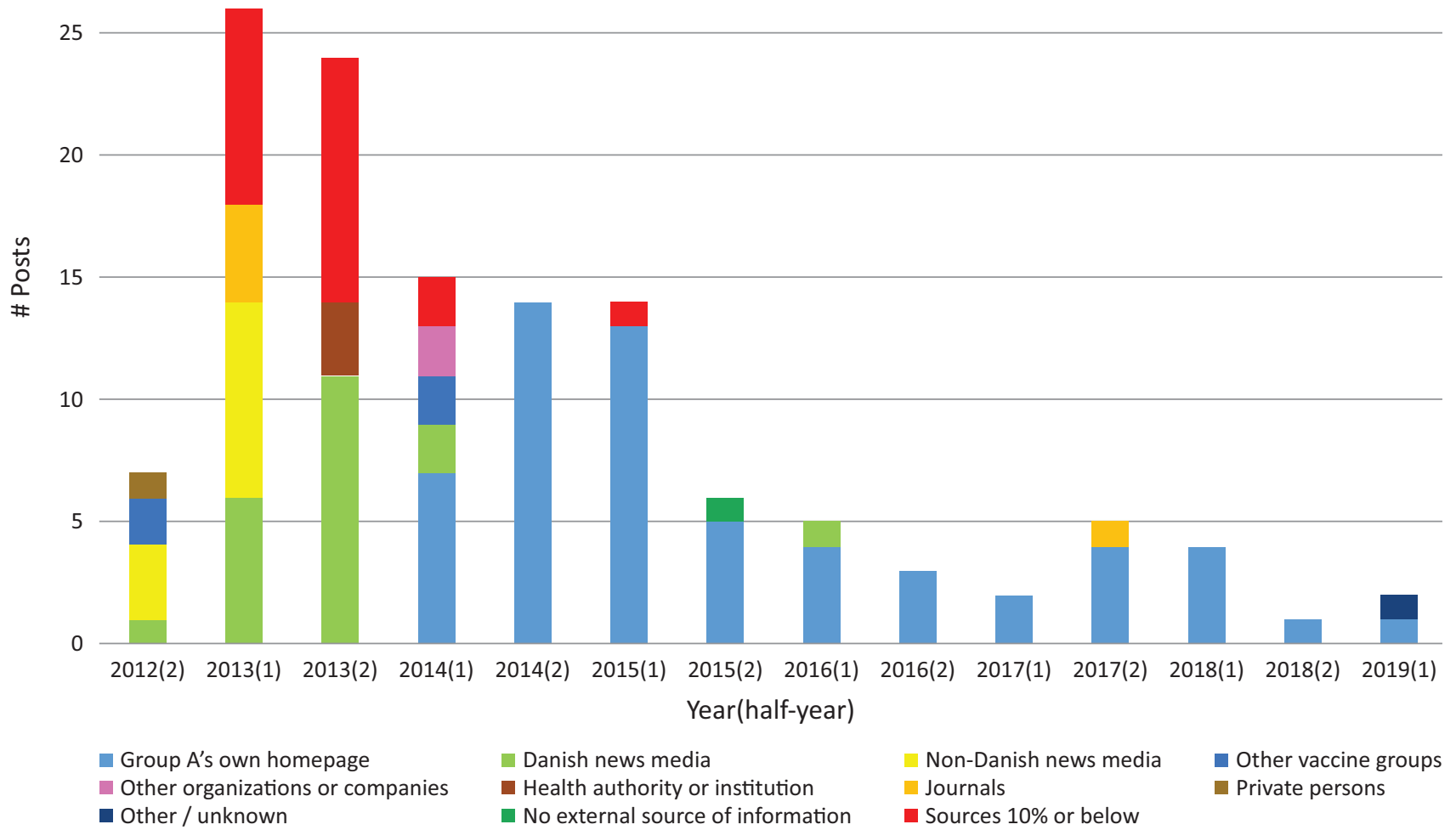

Figure 3. Sources of information on Page A until May 2019. Notes: In order to optimize data visualization, all sub-categories with relative frequencies of $10 \%$ or below have been merged into one (red section). For the same reason, we merged subcategories 'other' and 'unknown.' The same applies to Figure 4 and 5. 
lation), and suggested that the media coverage was misinformation staged by the Danish Cancer Society.

From 2014 onwards, the posts on Page A almost exclusively linked to articles published by Group A on its homepage. These posts served as short introductions to Group A's own information and often provided sensational or curious headlines such as "Gardasil will be the biggest medical scandal in history" (April 2014, authors' translation) and "The Cancer Society's dirty secret" (December 2015, authors' translation). Group A's articles on their homepage often were lengthy comments on topics of current interest, including recent events, news stories, research articles, or stakeholders' statements in the ongoing debate. In particular, Group A's writers were adamant about the role of the Danish Cancer Society in promoting HPV vaccination, more often than not insinuating that the Society conspired with pharmaceutical companies and the health authorities. One of the tags on Group A's homepage was "misinformation from the Cancer Society."

Group A was originally established because of alleged censorship on the Danish Cancer Society's Facebook pages (HPV Vaccine Info, 2020). Whether this is directly connected to the fact that the administrators of Page $A$ seemed particularly concerned with exposing conflicts of interest in the established healthcare system, locally, nationally, and internationally, we, of course, cannot say for sure.
However, we did find that the dominant topic of the administrators' supplementary text in posts was healthcare systems. The national healthcare system featured in $33.3 \%$ of all posts, and the international health care system in $26.2 \%$. The administrators often expressed general mistrust of key actors in Danish healthcare, such as The Danish Health Authority, The State Serum Institute (Statens Serum Institut), and general practitioners, and often hinted at possible conflicts of interest due to close ties to international pharmaceutical companies. In September 2013, the administrators compiled a list of Danish news items about possible conflicts of interests, and the administrators remarked: "It is difficult to have faith in the system in Denmark. There are numerous examples of the industry influencing every corner of it" (HPV Vaccine Info, 2013b, authors' translation).

\subsection{Intertextuality on Page B}

Page B most frequently used Danish media as sources (see Figure 4). Established as a platform for public outreach for a group of patients seeking to gain recognition of symptoms that they associate with HPV vaccination, Page B provided meta-coverage of the ongoing debate, with emphasis on political issues. The linked items generally served to promote the claim that the politicians and healthcare actors were not paying enough attention to this problem nor responding appropriately to issues



Figure 4. Sources of information on Page B until May 2019. Note: See also additional information in caption to Figure 3. 
brought forth by patients. Headlines such as "Minister: We ought not to forget the ill girls" (authors' translation) and "HPV girls have to receive faster and better help" (authors' translation) support this claim.

It thus makes sense to understand Page B not only as outreach but also as part of Group B's struggle to obtain public visibility and political representation. This is perhaps most clearly seen in the 'we' that the administrators often used in their accompanying text to indicate that they are speaking on behalf of many patients. They expressed an urgent wish for better treatments, more research on the relation between their symptoms and HPV vaccination, increased visibility, and dialogue with politicians. Many posts, particularly in 2015 and early 2016, dealt with Group B's work to attain these goals. In May 2015, for example, administrators reported on the audience of Group B representatives with the Danish parliament's health care committee. Other posts shared news items with reporters interviewing Group B spokespersons.

Posts on Page B tied political issues to ontological and epistemological questions regarding the scale, frequency, and cause of the symptoms of Group B's patients. These questions were particularly prominent in the period after November 2015, where first the EMA report appeared and soon after other epidemiological studies on the relation between HPV vaccination and symptoms affiliated with other medical conditions such as Chronic
Fatigue Syndrome/Myalgic Encephalomyelitis (CFS/ME), POTS, and CRPS (Arbyn, Xu, Simoens, \& Martin-Hirsch, 2018; EMA, 2015; Feiring et al., 2017).

The administrators repeatedly challenged the scientific results by stating that the epidemiological and clinical studies were unable to take into account the lifeworlds of real patients. In September 2017, the page shared a link to the Med Science Research website, which claimed that "[t]here are thousands of scientific studies in the medical literature on the dangers of vaccine" (Med Science Research, 2017). The link referred to a series of studies, mainly case studies, reporting on individuals who have all experienced symptoms after HPV vaccination with Gardasil. By such means, the page refuted a pure epidemiological framing of the controversy and pertained instead to the promoting of research that aimed to explain the bodily experiences of individuals.

\subsection{Intertextuality on Page C}

Administered by representatives of the same patient group as Page $B$, Page $C$ has some of the same features, including repeated links to media stories regarding the safety of the vaccine (see Figure 5). Compared to Page B, however, we observed that Page $C$ more consistently incorporated personal stories of individual persons suffering from suspected adverse events. We are able to support this observation by noting that there were substan-

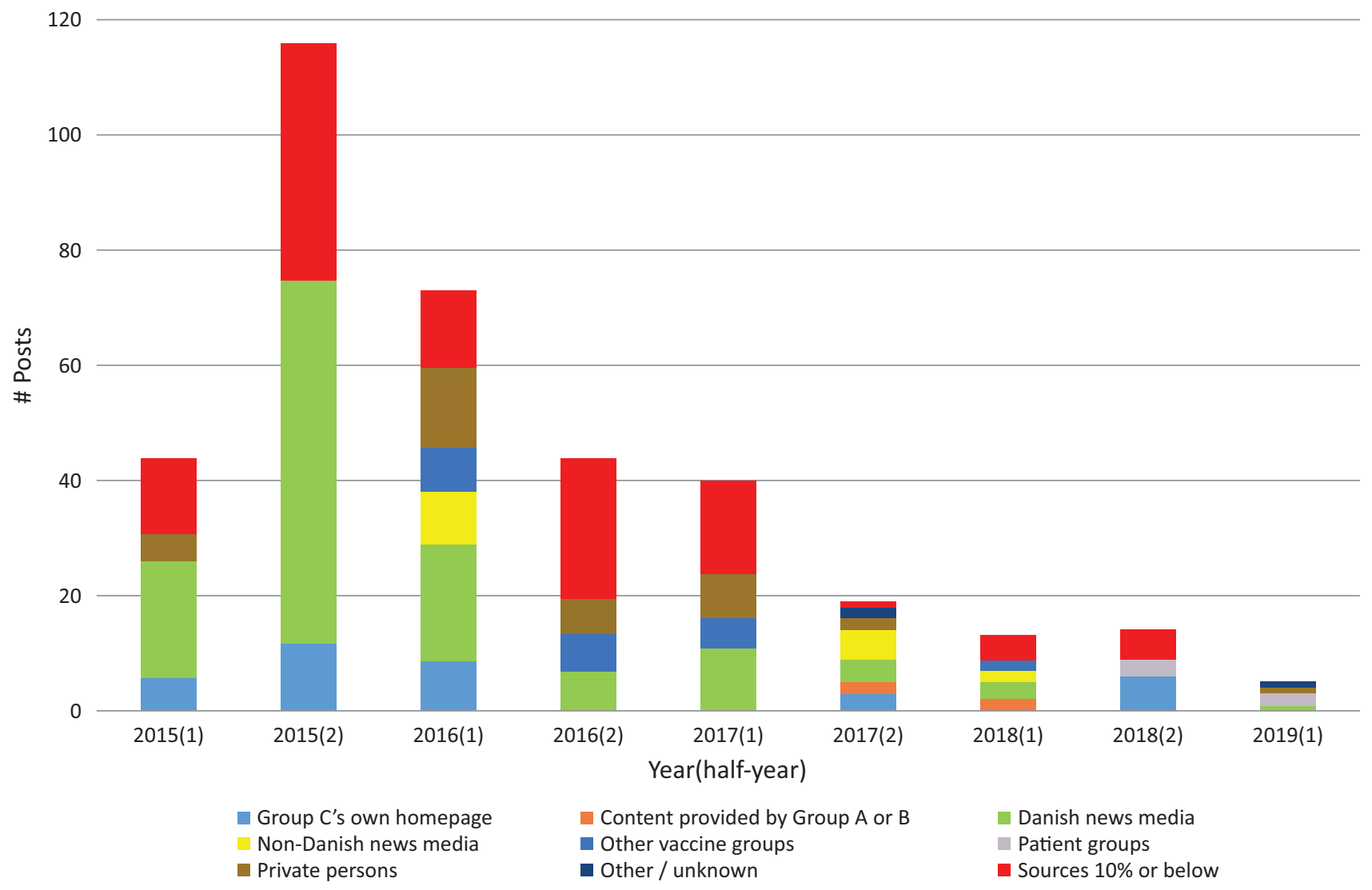

Figure 5. Sources of information on Page C until May 2019. Note: See also additional information in caption to Figure 3. 
tially more links to private persons $(13.0 \%)$ on Page $C$ compared to Page A (1.6\%) and Page B (2.0\%).

The sources for the 'private person' category were individuals, typically patients or their relatives, telling personal, often emotional, stories about suspected adverse events or complaining about the lack of recognition from the established medical authorities. The linked items included written accounts, images, videos, open letters, or poems or songs. For example, videos depicted girls who were visibly suffering from cramps, seizures, or syncope. Written accounts provided further details about the girls' medical condition, often reporting on lack of support or even disrespect from healthcare professionals and politicians. "Let's be honest. You haven't done a lot to help us," stated an open letter in January 2016 (Landsforeningen Hpv-bivirkningsramte, 2016a, author's translation). It was written by a named woman addressing the health minister at the time. Another letter reported on a meeting between a female patient and a general practitioner who called the woman "an 'attention hore [sic]"' (Landsforeningen Hpv-bivirkningsramte, 2016b, authors' translation).

The stories and visual materials served to create common visibility and shared understandings. One of the first videos posted in May 2015 was followed by a statement from the administrators expressing hope that the videos posted on their page would help open the eyes of everyone to the adverse events following HPV vaccination. Such statements might also be interpreted in terms of community-building as the posts were trying to tell everyone, including patients who could be unsure about the real cause of their symptoms, that there is a coherent but somewhat overlooked community of 'the afflicted' girls and their families.

Administrators of Page C used the term 'afflicted' (in Danish, 'ramt') as a shorthand for all those afflicted by adverse events after HPV vaccination, building a common identity and community. For example, the cover photo of Page C, as of December 2019, showed around 50 people standing in front of the Danish Parliament, most of them holding a red balloon. The photo was taken in December 2015 when the group had an audience with the Parliament's Health Committee. According to the accompanying content provided by the administrators, the balloons were meant to symbolize all the afflicted who at the time were unable to attend the meeting. While images and content such as this mainly spoke to the national community of the afflicted, several posts on Page $C$ also emphasized that the community was international in scope. "The patient group for HPV-injured [sic] in Ireland, R.E.G.R.E.T. is struggling as well. The HPV scandal is global" (Landsforeningen Hpv-bivirkningsramte, 2016c, authors' translation), an August 2016 post remarked.

The idea of an overlooked or even marginalized community became even more pronounced later on. In 2017 and 2018, administrator texts were generally longer, and the number of posts decreased. We also found in this period more references to the healthcare system. In 2017, for example, more than half of the posts referred to national healthcare actors such as the Danish Health Authority, the Danish Medicines Agency, or the Danish Cancer Society. These posts were often explicit in their critique of the established healthcare system and in positioning the community of the afflicted in opposition to the healthcare system.

From September 2017 and onwards, the administrators captured the oppositional stance of the community by adding this message to almost all posts:

We are not supported by the pharmaceutical industry, so with a budget of $1 / 1000$ of what The Cancer Society and the National Board of Health spend on their propaganda program, we are engaged in an uneven fight for equity for our many seriously ill young persons. (Landsforeningen Hpv-bivirkningsramte, 2017, authors' translation)

Like Page $B$ administrators, Page $C$ administrators used ' $w e^{\prime}$ to build a separate identity for the afflicted. The notion of "an uneven fight for equity" suggests that 'we' are in a disadvantageous position compared to others with more resources and more impact (Landsforeningen Hpv-bivirkningsramte, 2017, authors' translation). There is also the implied corollary that the 'others' intentionally wanted to oppress or silence 'us.' "This lack of debate and focus on the many young people invalidated after their injection of Gardasil seems to be the greatest collective societal betrayal in newer time" (Landsforeningen Hpv-bivirkningsramte, 2018, authors' translation), the administrators lamented in January 2018.

\section{Conclusion}

We have explored how three Danish Facebook pages dedicated to critical debate about HPV vaccination assemble different topics and sources. The three pages have ranked among the most prominent and most active social media sites in the Danish HPV controversy from 2012 to 2019. We find that they all form a complex and shifting assemblage of information, assertions, expressions of community, and more. Our results are limited to topics and sources that appeared on the administrators' posts in the context of the ongoing controversy where media attention to HPV vaccination was relatively high. We were not able to address visitors' comments in order to see how they entered into the assemblage, nor have we been able to gain access to the administrators to hear about their motives. Such topics might be of interest for further studies.

Our most important specific findings include:

- All three pages focused on adverse events following HPV vaccination and the national healthcare system. The administrators across all three pages agreed that there was - is - a connection between HPV vaccination and the appearance or worsen- 
ing of certain symptoms. They also agreed that the healthcare system responded inadequately to patients reporting adverse events from HPV vaccination. Often, conflicts of interest were evoked to explain why healthcare providers were reluctant to address adverse events from the point of view of those who claimed to be suffering;

- All three pages were closely linked to the public debate in Denmark as Danish news media were the most frequently used sources of information. We estimate that at least $36 \%$ of our 699 posts referred to stories reported by Danish journalists. We also found that news stories adopting a critical attitude towards HPV vaccination, for example by reporting on 'afflicted girls,' were shared more often than news stories reporting on scientific studies showing that HPV vaccination is safe;

- Beyond their common preference for sharing and commenting on stories in Danish news media, the three pages differed in their intertextual approaches. Page A mostly shared news stories and links to Group A's own homepage, where members of Group A claimed that the pharmaceutical companies have been a major force behind the introduction and promotion of HPV vaccination in Denmark. Page B administrators used their links to express concern about the lack of political and epistemic representation of the patients suffering from suspected adverse events. Page $C$ administrators shared this concern to which they added personal narratives and content portraying the afflicted as an overlooked, yet strong community that deserves recognition and respect.

What the list above shows is that making HPV vaccine assemblages can be a daunting task. It proceeds from the premise that HPV vaccination is a moving target that can be approached from many perspectives and not only based on scientific knowledge. With their intimate relationship with the public debate that goes on in the traditional news media, the HPV vaccine assemblages that we have studied were contextual and contingent in nature. In the early stages of the controversy, we found a near-symbiotic relationship with the news media's reporting of new cases of adverse events following HPV vaccination. In the later stages where the news media aligned with health authorities, assembling the HPV vaccine on the three pages seemed to become more difficult. The administrators met this challenge in different ways. Page $A$ became more introvert, referring mainly to its own contributions. Page B questioned the epistemic basis of epidemiological studies by pointing out that such studies failed to account for the actual life-worlds of patients. Page $\mathrm{C}$ focused more narrowly on the community of patients that felt betrayed by politicians, the media, and the healthcare system.

As already mentioned, the concept of vaccine assemblages is the social media counterpart to 'vaccine anxiety' discussed by Leach and Fairhead (2007). They studied parents, mostly mothers, who weighed different kinds of information from different dimensions, scientific as well as personal, social, cultural, financial, and political information, to reach a final decision about whether to have one's child vaccinated or not. We propose seeing the construction of HPV vaccine assemblages that was carried out on the three vaccine-critical pages as somewhat equivalent to this complex and anxious process of making up one's mind. The information that appeared on the pages embraced all the dimensions mentioned by Leach and Fairhead (2007). As the assembling process continued, it became harder for visitors - and analysts - to take the different dimensions apart and assess them independently of each other. And if the pages were 'taken apart' in the sense that their different streams of information were sorted in analytic categories, then maybe also the meanings that they would convey to specific persons at a specific time and place were rendered obsolete.

The vaccine assemblages metaphor is also relevant to understanding the vaccine communication environment discussed by Kahan (2017). As Kahan (2017) observes, the vaccine communication environment is 'protected' unless other antagonistic discussions become associated with the vaccine in question. Unlike the HPV vaccination controversy in the United States where strong opinions about teenage sexuality 'polluted' the debate, the Danish controversy brought together uncertainties over HPV vaccination safety and the proper treatment of medical conditions such as POTS, CRPS, and $\mathrm{CFS} / \mathrm{ME}$. Protecting the HPV vaccination environment in the Danish context, we believe, is not about designating certain vaccine assemblages as pollution, but rather of reassembling HPV vaccination in a way that addresses the sum total of what has become associated with the vaccine. In other words, protection and pollution are not neatly separated processes but rather different aspects of the process of building vaccine assemblages.

Vaccine criticism and misinformation on social media are growing concerns, and rightly so. How we address these issues depends on how we understand them. We contribute to our understanding of vaccine-critical pages by placing their criticism firmly in the national context in which it occurs and by portraying the patchwork of online vaccination criticism as vaccine assemblages. The three pages, as we have already indicated, thrived on media attention to HPV vaccination, combining found bits and pieces from the media debate with other sources to form complex and fluid assemblages around adverse events and the health care system (perceived as failed and corrupt). Vaccine assemblages reflect, but also affect the debate. What really counts for vaccine assemblages is not so much getting the scientific facts about HPV vaccination straight but gaining recognition, getting fair treatment, expressing doubts and anxieties, making value assertions, exposing conflicts of interest in the medical establishment, and much more. 


\section{Acknowledgments}

We are grateful to the three anonymous reviewers, the thematic issue guest editors, and the journal editors for useful comments. We would like to thank Cogitatio's editing service for English language editing and the Novo Nordisk Foundation for financial support (Grant No. NNF17SA0031308).

\section{Conflict of Interests}

The authors declare no conflict of interests.

\section{References}

Amdisen, L., Kristensen, M. L., Rytter, D., Mølbak, K., \& Valentiner-Branth, P. (2018). Identification of determinants associated with uptake of the first dose of the human papillomavirus vaccine in Denmark. Vaccine, 36(38), 5747-5753. https://doi.org/10.1016/ j.vaccine.2018.08.006

Arbyn, M., Xu, L., Simoens, C., \& Martin-Hirsch, P. P. (2018). Prophylactic vaccination against human papillomaviruses to prevent cervical cancer and its precursors. The Cochrane Database of Systematic Reviews, 5(5), CD009069. https://doi.org/10.1002/14651858. CD009069.pub3

Basch, C. H., \& MacLean, S. A. (2019). A content analysis of HPV related posts on Instagram. Human Vaccines \& Immunotherapeutics, 15(7/8), 1476-1478. https:// doi.org/10.1080/21645515.2018.1560774

Bean, S. J. (2011). Emerging and continuing trends in vaccine opposition website content. Vaccine, 29(10), 1874-1880. https://doi.org/10.1016/j.vaccine.2011. 01.003

Bucher, T., \& Helmond, A. (2017). The affordances of social media platforms. In J. Burgess, A. Marwick, \& T. Poell (Eds.), The Sage handbook of social media (pp. 233-253). London: SAGE.

Burki, T. (2019). Vaccine misinformation and social media. The Lancet Digital Health, 1(6), e258-e259. https://doi.org/10.1016/S2589-7500(19)30136-0

Cohen, J. (1960). A coefficient of agreement for nominal scales. Educational and Psychological Measurement, 20(1), 37-46. https://doi.org/10.1177/ 001316446002000104

European Centre for Disease Prevention and Control. (2012). Introduction of HPV vaccines in EU countries: An update. Stockholm: European Centre for Disease Prevention and Control.

European Medicines Agency. (2015). Assessment report review under Article 20 of regulation (EC) No 726/2004: Human papillomavirus (HPV) vaccines. London: European Medicines Agency.

Fairclough, N. (2003). Analysing discourse: Textual analysis for social research. London and New York, NY: Routledge.

Feiring, B., Laake, I., Bakken, I. J., Greve-Isdahl, M.,
Wyller, V. B., Haberg, S. E., . . . Trogstad, L. (2017). HPV vaccination and risk of chronic fatigue syndrome/myalgic encephalomyelitis: A nationwide register-based study from Norway. Vaccine, 35(33), 4203-4212. https://doi.org/10.1016/j.vaccine.2017. 06.031

Ghebreyesus, T. A. (2019). Vaccine misinformation: Statement by WHO director-general on Facebook and Instagram. World Health Organization. Retrieved from https://www.who.int/news-room/detail/0409-2019-vaccine-misinformation-statement-bywho-director-general-on-facebook-and-instagram

Guidry, J. P. D., Carlyle, K., Messner, M., \& Jin, Y. (2015). On pins and needles: How vaccines are portrayed on Pinterest. Vaccine, 33(39), 5051-5056. https:// doi.org/10.1016/j.vaccine.2015.08.064

Hoffman, B. L., Fetter, E. M., Chu, K. H., Shensa, A., Hermann, C., Wolynn, T., . . Primack, B. A. (2019). It's not all about autism: The emerging landscape of antivaccination sentiment on Facebook. Vaccine, 37(16), 2216-2223. https://doi.org/10.1016/j.vaccine.2019. 03.003

HPV-update. (2017). Vi er ikke en anti-vaccineorganisation [We are not an anti-vaccination organization]. HPV-update. Retrieved from https://hpvupdate. com/vi-er-ikke-en-anti-vaccineorganisation

HPV Vaccine Info. (2013a, June 24). Er der andre der har følt sig overvældet over misinformationen i medierne den sidste tid? Nedenstående er blot et meget [Has anyone else felt overwhelmed by the misinformation in the media lately? This is just a very] [Facebook status update]. Retrieved from https://dadk.facebook.com/hpvvaccineinfo/photos/ a.340798039371787/406489389469318

HPV Vaccine Info. (2013b, September 27). Endnu et eksempel i striben af danske læger, der er i lommen på medicinalindustrien. De mennesker der burde rådgive og [Yet another example of Danish physicians who are in the pocket of the pharmaceutical industry. The people who ought to guide and] [Facebook status update]. Retrieved from https://www.facebook. com/hpvvaccineinfo/posts/451847038266886

HPV Vaccine Info. (2020). Om os [About us]. HPV Vaccine Info. Retrieved from http://hpv-vaccine-info. org/om-os

Jakobsen, L. H. (2016). Holdning til HPV-vaccination: En kvantitativ undersøgelse blandt forældre med døtre pp. 10-13 år [Attitudes to HPV vaccination: A quantitative survey of parents with daughters ages 10-13 years]. Copenhagen: Kræftens Bekæmpelse. Retrieved from https://www.cancer.dk/dyn/resources/ File/file/7/6837/1511351588/rapport_hpv-survey08.09.16.pdf

Kahan, D. M. (2017). Protecting or polluting the science communication environment? The case of childhood vaccines. In K. H. Jamieson, D. M. Kahan, \& D. A. Scheufele (Eds.), The Oxford handbook of the science of science communication (pp. 421-432). Oxford: Ox- 
ford University Press.

Kahan, D. M., Braman, D., Cohen, G. L., Gastil, J., \& Slovic, P. (2010). Who fears the HPV vaccine, who doesn't, and why? An experimental study of the mechanisms of cultural cognition. Law and Human Behavior, 34(6), 501-516. https://doi.org/10.1007/ s10979-009-9201-0

Kata, A. (2012). Anti-vaccine activists, Web 2.0, and the postmodern paradigm: An overview of tactics and tropes used online by the anti-vaccination movement. Vaccine, 30(25), 3778-3789. https://doi.org/ 10.1016/j.vaccine.2011.11.112

Landsforeningen Hpv-bivirkningsramte. (2016a, January 24). BREV NR.1 THERESA "LAD OS VAERE AERLIGE,I HAR JO IKKE GJORT DET STORE FOR OS" Kære SOphie Løhde. Ang. [LETTER NO. 1 THERESA “LET'S BE HONEST.YOU HAVE NOT DONE A LOT TO HELP US" Dear Sophie Løhde. Re.:] [Facebook status update]. Retrieved from https://www.facebook.com/ HPVbivirkningsramte.dk/posts/1742798549286244

Landsforeningen Hpv-bivirkningsramte. (2016b, January 31). BREV NR. 8-Johanne "EN LAEGE HAR SÅGAR SAGT, AT JEG ER EN 'ATTENTION HORE' (OPMAERKSOMHEDSLUDER)" Hej Mit navn er [LETTER NO. 8-Johanne "A PHYSICIAN ONCE EVEN SAID THAT I'M AN 'ATTENTION HORE' (ATTENTION WHORE)" Hi My name is] [Facebook status update]. Retrieved from https://www.facebook.com/ HPVbivirkningsramte.dk/photos/ a.1660440077522092/1745375349028564

Landsforeningen Hpv-bivirkningsramte. (2016c, August 24). Irlands HPV Skade patientforening, R.E.G.R.E.T kæmper også. HPV Skandalen er global [The patient group for HPV injured in Ireland, R.E.G.R.E.T. is also fighting. The HPV scandal is global.] [Facebook status update]. Retrieved from https://www. facebook.com/HPVbivirkningsramte.dk/posts/ 1829381480627950

Landsforeningen Hpv-bivirkningsramte. (2017, September 27). DEL GERNE denne tankevækkende artikel og overvej selv, hvem du kan stole på? http:// yournewswire.com/pfizer-gardasil-vaccine/ I morgen kan det være dit [SHARE IF YOU LIKE this thought provoking video and reflect upon who you can count on? http://yournewswire.com/pfizergardasil-vaccine/ Tomorrow, it could be your] [Facebook status update]. Retrieved from https:// www.facebook.com/HPVbivirkningsramte.dk/posts/ 2022902581275838

Landsforeningen Hpv-bivirkningsramte. (2018, January 3). Lad os booste 2018 med et gensyn med "De vaccinerede Piger." For blot små 3 år siden levede vi stadig [Let us give 2018 a boost by reviewing "The vaccinated Girls." Just 3 years ago we were still living] [Facebook status update]. Retrieved from https:// www.facebook.com/HPVbivirkningsramte.dk/posts/ 2066731373559625

Larson, H. J. (2018). The biggest pandemic risk? Viral mis- information. Nature, 562(7727), 309-309. https:// doi.org/10.1038/d41586-018-07034-4

Latour, B. (2005). Reassembling the social: An introduction to actor-network-theory. Oxford: Oxford University Press.

Leach, M., \& Fairhead, J. (2007). Vaccine anxieties: Global science, child health and society. London: Earthscan.

Lombard, M., Snyder-Duch, J., \& Bracken, C. C. (2002). Content analysis in mass communication: Assessment and reporting of intercoder reliability. Human Communication Research, 28(4), 587-604. https:// doi.org/10.1093/hcr/28.4.587

Ma, J. X., \& Stahl, L. N. (2017). A multimodal critical discourse analysis of anti-vaccination information on Facebook. Library \& Information Science Research, 39(4), 303-310. https://doi.org/10.1016/j.lisr.2017. 11.005

Med Science Research. (2017). Med science research. Med Science Research. Retrieved from https:// medscienceresearch.com

Moran, M. B., Lucas, M., Everhart, K., Morgan, A., \& Prickett, E. (2016). What makes anti-vaccine websites persuasive? A content analysis of techniques used by anti-vaccine websites to engender antivaccine sentiment. Journal of Communication in Healthcare, 9(3), 151-163. https://doi.org/10.1080/ 17538068.2016.1235531

Okuhara, T., Ishikawa, H., Okada, M., Kato, M., \& Kiuchi, T. (2018). Contents of Japanese pro- and anti-HPV vaccination websites: A text mining analysis. Patient Education and Counseling, 101(3), 406-413. https:// doi.org/10.1016/j.pec.2017.09.014

Ortiz, R. R., Smith, A., \& Coyne-Beasley, T. (2019). A systematic literature review to examine the potential for social media to impact HPV vaccine uptake and awareness, knowledge, and attitudes about HPV and HPV vaccination. Human Vaccines \& Immunotherapeutics, 17(7/8), 1465-1475. https://doi. org/10.1080/21645515.2019.1581543

Schmidt, A. L., Zollo, F., Scala, A., Betsch, C., \& Quattrociocchi, W. (2018). Polarization of the vaccination debate on Facebook. Vaccine, 36(25), 3606-3612. https://doi.org/10.1016/j.vaccine.2018.05.040

Schreier, M. (2012). Qualitative content analysis in practice. Los Angeles, CA: SAGE.

Smith, M. E. (2018). Mediedækningen af HPV-vaccinen i Danmark: Et studie af mediernes indflydelse på HPVdebatten fra 1991-2017 [Media coverage of the HPV vaccine in Denmark: A study of media impact on the HPV debate from 1991 to 2017] (Unpublished master's thesis). Aarhus University, Aarhus, Denmark.

Smith, N., \& Graham, T. (2017). Mapping the antivaccination movement on Facebook. Information, Communication \& Society, 22(9), 1-18. https://doi. org/10.1080/1369118X.2017.1418406

Statens Serum Institut. (2019). Fortsat stigning i HPVvaccination i 2018 [Continued increase in HPV vaccination in 2018]. Statens Serum Institut. Re- 
trieved from https://www.ssi.dk/aktuelt/nyheder/ 2019/fortsat-stigning-i-hpv-vaccination-i-2018

Sundhedsstyrelsen. (2007). Reduktion af risikoen for livmoderhalskræft ved vaccination mod humant papillomvirus (HPV): En medicinsk teknologivurdering [Reduction of cervical cancer risk by inoculation of human papillomavirus (HPV): A medical technology assessment]. Medicinsk Teknologivurdering, 9(1). Retrieved from https://www.sst.dk/ /media/ 38191187F19A446F8A0B7E41349D7A2C.ashx

Suppli, C. H., Hansen, N. D., Rasmussen, M., ValentinerBranth, P., Krause, T. G., \& Molbak, K. (2018). Decline in HPV-vaccination uptake in Denmark: The association between HPV-related media coverage and HPVvaccination. BMC Public Health, 18(1), 1-8. https:// doi.org/10.1186/s12889-018-6268-x

Tomeny, T. S., Vargo, C. J., \& El-Toukhy, S. (2017). Geographic and demographic correlates of autismrelated anti-vaccine beliefs on Twitter, 2009-15. Social Science \& Medicine, 191, 168-175. https://doi. org/10.1016/j.socscimed.2017.08.041

Ward, J. K. (2016). Rethinking the antivaccine movement concept: A case study of public criticism of the swine flu vaccine's safety in France. Social Science \& Medicine, 159, 48-57. https://doi.org/10.1016/ j.socscimed.2016.05.003

Ward, J. K., Peretti-Watel, P., Larson, H. J., Raude, J., \& Verger, P. (2015). Vaccine-criticism on the internet: New insights based on French-speaking websites. Vaccine, 33(8), 1063-1070. https://doi.org/ 10.1016/j.vaccine.2014.12.064

Ward, J. K., Peretti-Watel, P., \& Verger, P. (2016). Vaccine criticism on the Internet: Propositions for future research. Human Vaccines \& Immunotherapeutics, 12(7), 1924-1929. https://doi.org/10.1080/ 21645515.2016.1146430

World Health Organization. (2018). Denmark campaign rebuilds confidence in HPV vaccination. World Health Organization. Retrieved from http://www.euro. who.int/en/countries/denmark/news/news/2018/3/ denmark-campaign-rebuilds-confidence-in-hpvvaccination

Wolfe, R. M., Sharp, L. K., \& Lipsky, M. S. (2002). Content and design attributes of antivaccination web sites. JAMA, 287(24), 3245-3248. https://doi.org/ 10.1001/jama.287.24.3245

Yiannakoulias, N., Slavik, C. E., \& Chase, M. (2019). Expressions of pro- and anti-vaccine sentiment on YouTube. Vaccine, 37(15), 2057-2064. https://doi. org/10.1016/j.vaccine.2019.03.001

\section{About the Authors}
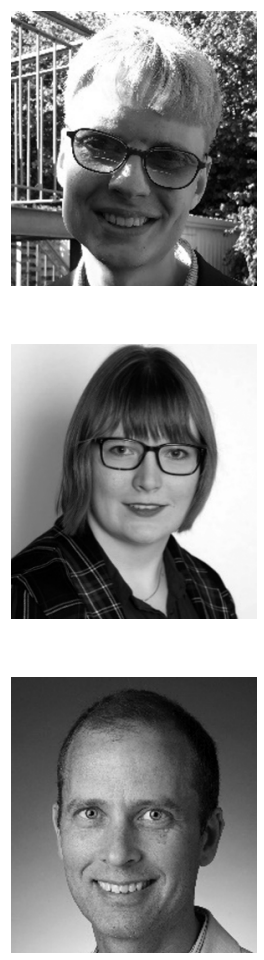

Torben E. Agergaard is a Research Assistant at the Centre for Science Studies, Aarhus University, Denmark. He holds a MSc Degree in Science Studies from Aarhus University, Denmark. His thesis revolved around content related to HPV vaccination on vaccine-critical Facebook pages in Denmark. Currently, he is working on two projects on HPV vaccination coverage and citizen science, respectively.

Màiri E. Smith worked as a Research Assistant at the Centre for Science Studies, Aarhus University, Denmark. She holds a MSc Degree in Science Studies from Aarhus University, Denmark. In her thesis, she analyzed media coverage of HPV vaccination in Denmark.

Kristian H. Nielsen is an Associate Professor at the Centre for Science Studies, Aarhus University, Denmark. His research interests cover science and health communication, public understanding of science, and history of science and technology. He is currently involved in three research projects on HPV vaccination in public media, citizen science in Denmark, and the history of scientific expeditions. 